\title{
IMPLEMENTING FLAC3D MODEL FOR SIMULATING DEFORMATION MECHANISM OF STEEL FRAME SUPPORT SET BY ACTUAL PROFILE
}

\author{
V. Nazymko ${ }^{1 *}$, V. Griniov ${ }^{1}$ \\ ${ }^{1}$ Institute for Physics of Mining Processes the National Academy of Sciences of Ukraine, Dnipropetrovsk, Ukraine \\ *Corresponding author: e-mail victor.nazimiko@yahoo.com, tel. +380504724729
}

\section{ЗАСТОСУВАННЯ FLАСЗD МОДЕЛІ ДЛЯ КОМП'ЮТЕРНОГО МОДЕЛЮВАННЯ МЕХАНІЗМУ ДЕФОРМУВАННЯ СТАЛЬНОГО РАМНОГО КРІПЛЕННЯ, ЯКЕ ЗАДАНЕ ЯВНИМ ПРОФІЛЕМ}

\author{
В. Назимко ${ }^{1 *}$, В. Гріньов ${ }^{1}$ \\ ${ }^{I}$ Інститут фізики гірничих процесів Національної академії наук Украӥни, Дніпропетровськ, Украӥна \\ *Bidnовідальний aвтор: e-mail victor.nazimiko@yahoo.com, тел. +380504724729
}

\begin{abstract}
Purpose. The problem of simulating steel frame irreversible deformation and displacement remains unsolved. The purpose of this research was to develop a new approach to simulation of frame yield support.

Methods. We used combination of different methods, namely FLAC3D model, benchmark tests and materialistic frames profile in the form of primitive proxies in place of standard structural elements, for instance, beams, which are actually mathematical lines that have abstract geometrical characteristics of the frame profile.

Findings. The research focused on the interaction of steel frame supports and the surrounding rocks during tail entry maintenance behind the longwall face to provide direct flow of air, which reduces methane explosion hazard.

Originality. The proposed profile model can be helpful as a practical tool that can assist in frame support improvement during complex interaction of rock massif with frame support in difficult geological and geomechanical conditions.

Practical implications. Owing to this approach, we were able to obtain practically all patterns of the actual frame profile behavior: frame turn and displacement, plastic hinge in coffering, longitudinal twisting and splitting, lateral bending, breakage and sliding in yield joints. Surprisingly, frame support behavior in computer model was extraordinary realistic despite primitive approximation of the frame profile, which demonstrates originality of the new approach.
\end{abstract}

Keywords: air gate, rock pressure, support, strains, computer simulation

\section{INTRODUCTION}

The problem of keeping stability of underground roadways in coal mines has remained urgent in spite of continuous improvement support, methods and means of maintaining roadways. This is particularly critical for the entries that have to be maintained behind the longwall faces to provide direct flow of air and methane that reduces gas explosion hazard. Despite extraordinary efficiency of the cable bolts, they failed to keep tail entry stability behind the longwall especially when pilllarless technology of mining is used. It is a commonly acknowledged practice to avoid pillar technology at deep horizons (800 $\mathrm{m}$ and more), because the pillars are exceptional concentrators of ground pressure that is a source of intensive deformations and dangerous dynamic effects.
Combination of steel arch support and rock bolts/cables is the most popular combined support so far that may provide sufficient resistance to ground pressure behind the longwall where undermined rock strata experience intensive subsidence. Such support has advantage due to synergetic effect between steel frames and rock bolts and is widely used in coal mines in Germany (Stahlmann, Missal \& Edel, 2014; Stenmans \& Hellwig, 2013), Poland (Korzeniowski, Plechota \& Stachowicz, 2000), Czech Republic (Šňupárek \& Konečný, 2010), Ukraine (Baisarov, 2001), and China (Guo, Wang \& Zhang, 2015; Qingbinet et al., 2015; Kang, 2014).

Nonetheless, even such synergy sometimes cannot provide sufficient stability of tail entries in soft rock because of the steel frames failure (Stenmans \& Hellwig, 
2013). Therefore, investigation of the steel frames behavior behind a longwall remains an urgent problem.

The most frequently used methods to evaluate efficiency of underground support are laboratory testing (Hadjigeorgiou \& Potvin, 2011; Tatone \& Grasselli, 2015) and actual measurement of ground movement and support deformation (Yu, Zhao, Kuang \& Meng, 2015; Zhang, Bai \& Chen, 2015). Results of such tests and measurements provide very important if limited data because of cramped underground conditions, difficulty of access into rock mass and safety concerns. Computer simulation is the most comprehensive method that provides virtually unlimited amount of information concerning rock mass and roadway support behavior.

\section{SIMULATION METHODOLOGY}

Mining support operates in close contact with the surrounding rock mass. Therefore, simulation tool should be able not only to imitate interaction of rock mass and support but reflect their mechanical properties including selection of relevant constitution models. To date, FLAC3D and 3DEC are the most sophisticated tools for simulation such complex geomechanic processes (FLAC3D, 2008). Special structural elements have been introduced to simulate rock/cable bolts, lining and steel frames. These elements have all the necessary mechanical properties and some major geometric features. For example, the beam structural element has cross-sectional area, both second moments and the polar moment of inertia. However, the structural elements have no physical bodies and are limited by one or two dimensions. It is important to know the actual shape of the frame profile after its collapse because such additional information promotes understanding of complex interaction between the support and the surrounding rock mass. Therefore, it is desirable to reduce structural elements to the frame members that have actual profile shape and dimensions.

However, the least dimension of the structural elements is an order of magnitude less in comparison with the roadway and surrounding rock mass sizes. Unfortunately, not only FLAC3D but any numerical method provides a stable mathematical solution while dimensions of the zones or finite elements which decompose adjacent continuums are comparable. To mitigate this contradiction, special member elements have been introduced into FLAC3D to simulate mechanical properties of steel arches, rock bolts trusses and girds. However, these members are mathematical entities and are represented by lines. Therefore, an array of effects could not be simulated. For instance, plastic hinge might be simulated at an assigned point of a steel frame only.

In this research, we tested an approach when the real shape of a steel frame support has been changed to a rough, approximate shape that allowed to divide the frame into zones of comparable sizes with the dimensions that represent the surrounding rock mass. Figure 1, A demonstrates arch member section of an actual steel frame profile in the place where adjacent members overlap each other to form a yield effect due to reciprocal sliding. Fragments B, C, D illustrate options of the primitive overlap substitutes: options $\mathrm{D}$ and $\mathrm{C}$ provide vertical plane contact with the adjacent members, whereas frag- ment D shows Z-shaped contact that consists of horizontal and vertical components of the contact. Furthermore, $\mathrm{D}$ option provides a more reliable joint of the frame members because the joint is secured with both mechanic properties and geometric features of the contact. Namely, D option makes it impossible to disintegrate the joint in horizontal direction if a frame member is rigid. Mechanic adhesion of the members was simulated with the interface, which has tension and shear limits.

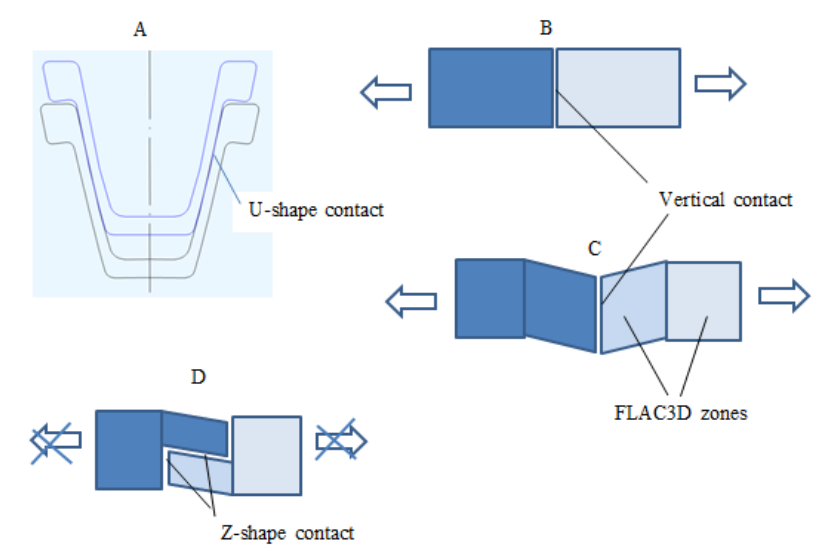

Figure 1. Different shapes of a member section at the joint: (A) real profiles of the steel frame that create; $U$-shape contact; $(B, C)$ tangible substitutes of the real profile that create vertical contact; (D) substitute that creates $Z$-shape contact which prevents horizontal disintegration of the members

Mechanical properties of the surrounding rocks represent strata of a typical Ukrainian coal mine and are indicated in Table 1, where bulk, shear module, cohesion, angle of friction, tension limits and angle of dilation are listed for the roof, immediate roof, coal seam, immediate floor and the floor.

Table 1. Mechanical properties of the surrounding roadway rocks

\begin{tabular}{ccccccc}
\hline $\begin{array}{c}\text { Type of } \\
\text { rock }\end{array}$ & $\begin{array}{c}\text { Bulk } \\
\text { module, module, } \\
\mathrm{Pa}\end{array}$ & $\begin{array}{c}\text { Shear } \\
\mathrm{Pa}\end{array}$ & $\begin{array}{c}\text { Cohe- } \\
\text { sion, Pa }\end{array}$ & $\begin{array}{c}\text { Angle of } \\
\text { friction, } \\
\text { degree }\end{array}$ & $\begin{array}{c}\text { Tension } \\
\text { limit, Pa }\end{array}$ & $\begin{array}{c}\text { Angle of } \\
\text { dilation, } \\
\text { degree }\end{array}$ \\
\hline $\begin{array}{c}\text { Roof } \\
\text { Immediate }\end{array}$ & $4 \cdot 10^{9}$ & $3 \cdot 10^{9}$ & $1 \cdot 10^{6}$ & 30 & $1 \cdot 10^{5}$ & 35 \\
$\quad$ roof & $3 \cdot 10^{9}$ & $2.2 \cdot 10^{9}$ & $0.5 \cdot 10^{6}$ & 25 & $1 \cdot 10^{5}$ & 35 \\
$\begin{array}{c}\text { Coal seam } \\
\text { Immediate }\end{array}$ & $1 \cdot 10^{9}$ & $0.6 \cdot 10^{9}$ & $0.5 \cdot 10^{6}$ & 30 & $1 \cdot 10^{5}$ & 15 \\
floor & $1.5 \cdot 10^{9}$ & $1 \cdot 10^{9}$ & $1 \cdot 10^{6}$ & 25 & $1 \cdot 10^{5}$ & 35 \\
Floor & $3 \cdot 10^{9}$ & $2 \cdot 10^{9}$ & $2 \cdot 10^{6}$ & 35 & $2 \cdot 10^{5}$ & 25 \\
\hline
\end{tabular}

Mohr-Coulomb constitutive model was used to control the process of rock mass destruction.

Tension and shear limits of steel were $150 \mathrm{MPa}$ and $100 \mathrm{MPa}$ respectively. Properties of interface between adjacent members of the frame were as follows: normal stiffness, $1 \cdot 10^{10} \mathrm{~Pa}$; tangential stiffness, $1 \cdot 10^{8} \mathrm{~Pa}$; angle of friction, $20^{\circ}$; cohesion, $30000 \mathrm{~Pa}$. Properties of the interface between rock mass and steel frames were the same excluding the cohesion assigned to zero.

The gob has been simulated explicitly. Thickness of a coal seam was $1.8 \mathrm{~m}$. Crib has been erected immediately 
after coal extraction. Properties of the crib material were the same as the coal seam. Depth of mining was $800 \mathrm{~m}$.

Simulation has been accomplished in four stages. First, in situ, stress state at the depth of $800 \mathrm{~m}$ was simulated assigning elastic model to the virgin rock mass. After this, the model shifted to Mohr-Coulomb and tail entry was driven in the stressed rock mass. At the next stage, rock bolts, cables and two steel frames were installed. The distance between steel frames was $0.8 \mathrm{~m}$. Bolts and cables were placed between the frames. It is noteworthy that steel frames were yieldable. Finally, a longwall face created the gob at the right side of the entry during the fourth stage. This entry was maintained with a pumped crib that had the same mechanical properties as the coal seam extracted.

\section{RESULTS AND DISCUSSION}

Figure 2 demonstrates FLAC3D model for the options $\mathrm{B}$ and $\mathrm{D}$ of the joints between steel frame members. A model was used earlier for simulation of a combined rigid frames and rock bolts behavior using standard FLAC3D cable and beam structural elements. We will use this standard model for comparing results of simulation with those for the proxies B, C, D of steel frame profile. The width of both models was $2 \mathrm{~m}$. The structure of these models and rock mass properties were practically identical. Horizontal displacements of the vertical walls of the models were forbidden. Model bottoms were immovable. Simulation has been performed in the large mode of deformation.

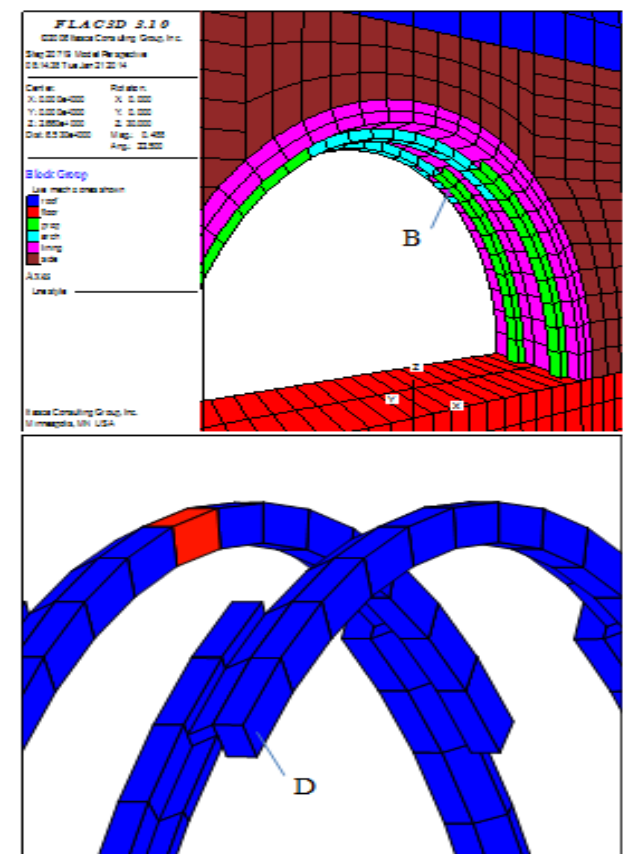

Figure 2. Options of arch frame members contact

Figure 3 depicts tension distribution in the rock bolts (short) and cables (long) in fragment A. Delamination of the roof layers caused the loss of contact between the bolts and rock mass at their ends (indicated by cycles). The cables broke this contact on the entry cavity side only. Some cables and bolts became curved which may be explained by intensive disintegration of the immediate roof.

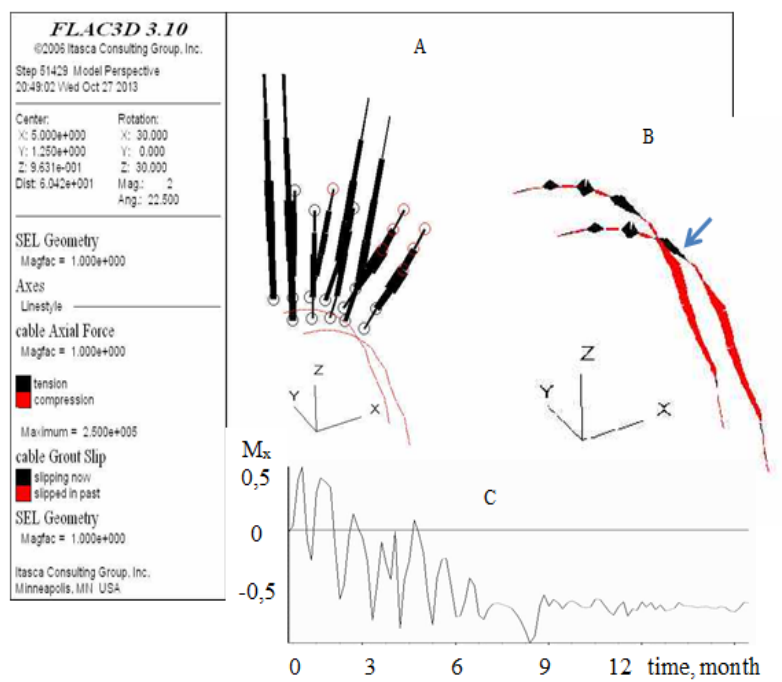

Figure 3. Tension distribution in the rock bolts and cables (A); twisting moments in the steel rigid frames (B); and dynamics of the moment as time elapsed $(C)$

Fragment B demonstrates distribution of the twist moment along the frame bodies. Axis of the twisting moment coincides with the axis of a frame member. Sign of the moment alters from the clockwise to left-handed and vice versa in several intervals of the frame. Furthermore, the twisting moment varied over time. This is depicted in the diagram fragment $\mathrm{C}$ in Figure 3.

The diagram has been plotted for the point indicated with an arrow in fragment $\mathrm{B}$. The horizontal axis is scaled in months conventionally. At the beginning, twisting of the frame member was positive, however the trend shifted gradually to negative. In addition, the moment had fluctuated severely during the active stage of the frame deformation. This fluctuation subsided after stabilization of the ground movement process. It should be stressed that both frames were at the same positions relativeto the adjacent rock mass despite large deformation.

Figures 4 to 6 demonstrate peculiarities of the frames behavior during simulation using the substituted frame profiles. Position 1 in Figure 4 indicates peculiar behavior of the frames that manifested in their displacement. In reality, frames are fixed in a roadway with spacers or girders, which have a tendency to collapse due to intensive deformation.

Rupture of the spacers occurs frequently due to turning of the frames in the cramped and confined entry that intensively reduces dimensions behind a longwall face. Props of the frames punch and immerse to the heaving floor that fixes them. Therefore, only the upper part of the frame preserves degree of freedom and might turn and displace in respect to the surrounding rocks. This displacement is so large that adjacent frames might come to contact as can be seen in Figure 4.

Another form of inelastic irreversible deformation is twisting of the frame profile (position 2). The twisting is an alternative way to match with the process of reduction of entry dimensions behind the longwall. The same effect occurs due to breakage of joints between frame members and disintegration of the frames. All irreversible effects indicated are the results of a fundamental and well known law of mechanics. 

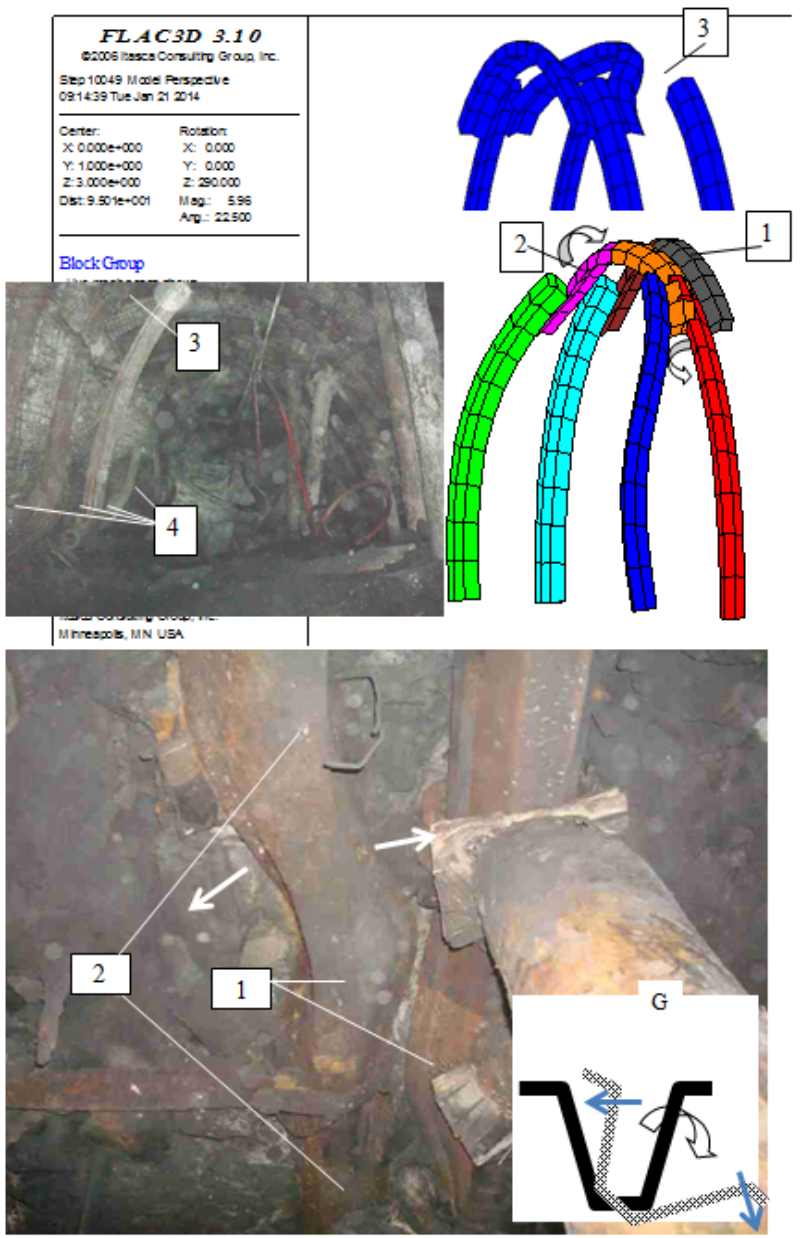

Figure 4. Illustration of twisting deformation (position 2) of the steel frames, their disintegration (position 3) and displacement (position 1); (G) demonstration of profile divergence

Namely, any mechanical system accepts a position and form at which its potential energy of deformation is minimal. It should be emphasized that such irreversible behavior of the frames occurred due to failure of yielding process in the joints.

Next form of frame irreversible deformation is manifested as plastic hinge, which occurs frequently at the vault part of the arch (Fig. 5, position 5). Such failure occurs in a short interval of the frame profile yet it reduces its bearing capacity dramatically. Often, seepage of aggressive ground water from the roof accelerates and boosts such negative effect due to undesirable synergy between corrosion and plastic deformation of steel.

Split of the frame steel profile reduces the moment of inertia and resistance of the frame to ground pressure. The example of such splitting is indicated in position 6 . Process of splitting occurs due to excess specific bending of a frame member when it obtains negative curvature (further-reverse bending). Arch straightens in the case.

Such bending is illustrated by position 4 in Figure 6 (fragment $\mathrm{C}$ ), and Figure 4. Props of the frames tend to bend and split frequently when they indent down to floor.

Standard structural elements cannot discover negative effects that have been registered with the tangible substitute of the frame profile.

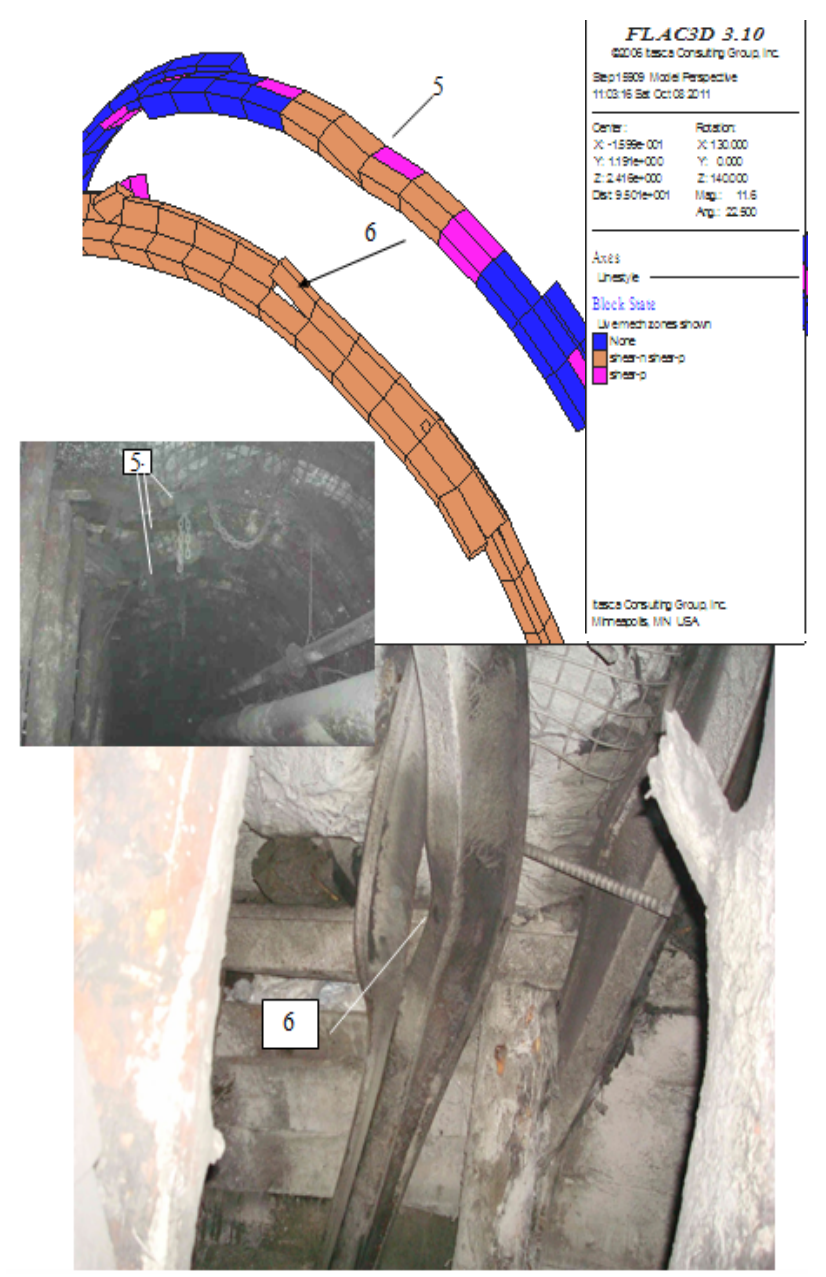

Figure 5. Plastic hinge (5) and splitting of the frames (6)

As far as the above mentioned structural elements are concerned, it is taken for granted that second moments and moment of inertia of the frame profile (e.g. geometrical moments) remain constant during any form of deformations including plastic.

However, simulation shows that the profile evolves in such a way that its ends diverge as indicated with arrows in fragment $G$ in Figure 4. Divergence of the profile flattens it. Process of profile flattening dramatically reduces its geometrical moments and therefore cuts bending resistance. Our simulation indicated that the most intensive divergence of the profile ends accompanies twisting and reverse bending of the frame profile. These findings are confirmed by actual observations of profile twisting (Fig. 4) and reverse bending (Fig. 5).

Jam or blockage of the sliding process is the main attribute that causes plastic deformation, turn and collapse of steel frames. Figure 6 demonstrates this effect. The front frame in fragment A yielded to 40 centimeters and $25 \mathrm{~cm}$ at both joints. This has had a positive impact on the frame stability. On the contrary, joints of the rear frame blocked that initiated damage of the joints (position 7).

Fragment B depicts a histogram that demonstrates good agreement between testing the joint in a laboratory and the results of computer simulation. The joint of frame members demonstrates sharp resistance at the beginning and stabilizes sliding force during slipping of the members relatively to each other. 


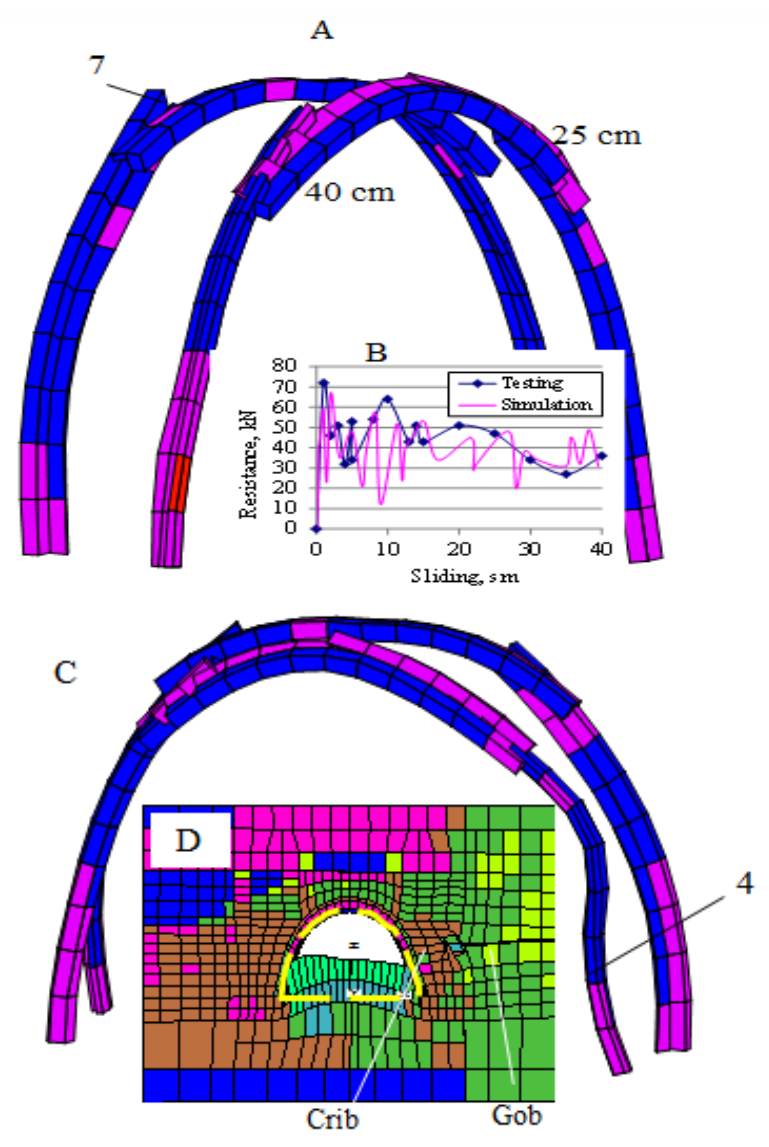

Figure 6. Demonstration of the frame yield: $(A, C)$ deformed frames; (B) monitoring of resistance the joints to mutual sliding of the frame members; (D) ground movement around tail entry behind a longwall

Some irreversible deformations of the steel frames are unavoidable in entry after passage of the longwall when immediate roof and floor of extracted coal seam converge (see fragments C and D in Figure 6). Plastic deformations of the frames are larger at the crib side of the tail entry which is intensively deformed due to closure the gob.

Surprisingly, primitive simple proxies that substituted real shape of the steel frame profile made it possible to reflect realistically the specific behavior of irreversible deformation of a frame support in underground roadway under unfavorable conditions. The proposed proxy models can be helpful for investigating a complex process of rock mass and roadway support interaction in adverse environment. Our findings provide additional information for improvement of the combined support design in weak surrounding rocks and intensive ground pressure.

\section{CONCLUSION}

Behavior of a steel yieldable frame support has been investigated with FLAC3D models for the most severe case when underground roadway is maintained behind the longwall face to provide direct flow of air and methane that reduces gas explosion hazard. To promote understanding of complex interaction of the support and surrounding rock mass, beam standard structural elements were substituted with primitive tangible proxies of real steel profile and frame members have been jointed through standard interfaces.
This allowed to simulate frame yielding explicitly and reproduce the peculiar effects of turning and displacement of the frames which decreases their stability and reduces bearing capacity. The same negative consequence is caused by twisting, plastic bending and splitting of frame profile, blockage and failure of yielding process in the sliding joints. All these effects were explicitly simulated using the proposed models.

Surprisingly, primitive simple proxies that substituted real shape of the steel frame profile made it possible to reflect realistically a specific behavior and irreversible deformation of a frame support in underground roadway under unfavorable conditions. Simulation shows that twisting and reverse bending of the frame profile caused the divergence of profile's ends that flattened it. The process of profile flattening dramatically reduces its geometrical moments and therefore cuts bending resistance as well as the bearing capacity of the frame support. The proposed proxy models can be helpful for investigating the complex process of rock mass and roadway support interaction in unfavorable geologic and geomechanic environment.

\section{ACKNOWLEDGEMENTS}

This article was supported by the National Academy of Science of Ukraine (grant S-3-12).

\section{REFERENCES}

Baisarov, L. (2001). Entry Maintenance with Pumped Cribs during Longwall Mining. Coal of Ukraine, 9, 3-5.

FLAC3D (2008). Fast Lagrangian Analysis of Continua in 3 Dimensions. Online Manual. Minneapolis, Itasca.

Guo, Z., Wang, J., \& Zhang, Y. (2015). Failure mechanism and supporting measures for large deformation of Tertiary deep soft rock. International Journal Of Mining Science And Technology, 25(1), 121-126. http://dx.doi.org/10.1016/j.ijmst.-2014.11.002

Hadjigeorgiou, J., \& Potvin, Y. (2011). A Critical Assessment of Dynamic Rock Reinforcement and Support Testing Facilities. Rock Mechanics and Rock Engineering, 44(5), 565-578. http://dx.doi.org/10.1007/s00603-011-0155-4

Kang, H. (2014). Support technologies for deep and complex roadways in underground coal mines: a review. International Journal Of Coal Science \& Technology, 1(3), 261-277. http://dx.doi.org/10.1007/s40789-014-0043-0

Korzeniowski, W, Plechota S., \& Stachowicz, S. (2000). Obudowa mieszana chodnikow przianowych w Kopalni Wegla Kamienego "Bogdanka". Wiadomosci Gorniczne, 4, 34-41.

Qingbin, M., Lijun, H., Jingwu, S., Min, F., Feng, W., \& Zhou, X. (2015). Experimental study on the bolt-cable combined supporting technology for the extraction roadways in weakly cemented strata. International Journal of Mining Science and Technology 25, 113-119. http://dx.doi.org/10.1016/j.ijmst.2014.11.010

Šňupárek, R., \& Konečný P. (2010). Stability of roadways in coalmines alias rock mechanics in practice. Journal of Rock Mechanics and Geotechnical Engineering, 2 (3), 281-288. http://dx.doi.org/10.3724/SP.J.1235.2010.00281

Stahlmann, J., Missal, C., Hahn, P., \& Edel, T. (2014). Geotechnical conditions at the Konrad mine - Excavation of drifts and rooms in squeezing rock. Mining Report, 150(5), 277-288. http://dx.doi.org/10.1002/mire.201400029

Stenmans, K., \& Hellwig, R. (2013). Operating experience with high-tempered steel roadway supports at West colliery. Mining Report, 149(S1), 37-47. http://dx.doi.org/10.1002/-mire.201300424

Tatone, B.S.A., \& Grasselli G. (2015). A calibration procedure for two-dimensional laboratory-scale hybrid finite-discrete ele- 
ment simulations. International Journal of Rock Mechanics and Mining Sciences, 75, 56-72.

http://dx.doi.org/10.1016/j.ijrmms.2015.01.011

Yu, B., Zhao, J., Kuang, T., \& Meng, X. (2015). In situ investigations into overburden failures of a super-thick coal seam for longwall top coal caving. International
Journal of Rock Mechanics and Mining Sciences, 78, $155-162$.

Zhang, Z., Bai, J., \& Chen Y. (2015). An innovative approach for gob-side entry retaining in highly gassy fully-mechanized longwall top-coal caving. International Journal of Rock Mechanics and Mining Sciences, 80, 1-11.

\section{ABSTRACT (IN UKRAINIAN)}

Мета. Проблема комп’ютерного моделювання незворотних деформацій і переміщень стального рамного кріплення залишається невирішеною. Метою цього дослідження була розробка нового підходу до комп’ютерного моделювання піддатливого рамного кріплення.

Методика. Ми застосували комбінацію різних методів дослідження, а саме: FLAC3D модель, стендові випробування а також матеріальний профіль рам у вигляді примітивних його замінників замість стандартних структурних елементів, наприклад балок, які є фактично математичними лініями, що мають абстрактні геометричні характеристики рамного профілю.

Результати. Досліджено взаємодію стального рамного кріплення та оточуючих його порід під час підтримки вентиляційної виробки позаду очисного вибою для забезпечення прямоточного провітрювання, що знижує небезпеку вибуху метану.

Наукова новизна. Запропонована модель профілю може бути корисним практичним інструментарієм, що допоможе вдосконалити рамне кріплення під час взаємодії породного масиву з рамним кріпленням в складних геологічних та геомеханічних умовах.

Практична значимість. Завдяки такому підходу, ми змогли отримати практично усі зразки поведінки рамного реального профілю: розворот рам у просторі і ̈̈х зсув, пластичні прогини у склеповій частині арок, поздовжнє скручування та розчеплення профілю, боковий згин, розрив та проковзування у замках піддатливості. На подив, поведінка рамного кріплення у комп'ютерній моделі була надзвичайно реалістичною, незважаючи на примітивну апроксимацію рамного профілю, що демонструє оригінальність нового підходу.

Ключові слова: вентиляційна виробка, гірський тиск, кріплення, деформації, комп'ютерне моделювання

\section{ABSTRACT (IN RUSSIAN)}

Цель. Проблема компьютерного моделирования необратимых деформаций и перемещений стального рамного крепления остается нерешенной. Целью этого исследования была разработка нового подхода к компьютерному моделированию податливого рамного крепления.

Методика. Мы применили комбинацию различных методов исследования, а именно: FLAC3D модель, стендовые испытания, а также материальный профиль рам в виде примитивных его заменителей вместо стандартных структурных элементов, например балок, которые являются фактически математическими линиями, имеющие абстрактные геометрические характеристики рамного профиля.

Результаты. Исследовано взаимодействие стального рамного крепления и окружающих его пород при поддержании вентиляционной выработки позади очистного забоя для обеспечения прямоточного проветривания, что снижает опасность взрыва метана.

Научная новизна. Предложенная модель профиля может быть полезным практическим инструментарием, который поможет усовершенствовать рамное крепление во время взаимодействия породного массива с рамным креплением в сложных геологических и геомеханических условиях.

Практическая значимость. Благодаря такому подходу, мы смогли получить практически все образцы поведения реального рамного профиля: разворот рам в пространстве и их смещение, пластические прогибы в сводовой части арок, продольное скручивание и расщепление профиля, боковой изгиб, разрыв и проскальзывания в замках податливости. На удивление, поведение рамного крепления в компьютерной модели было чрезвычайно реалистичным, несмотря на примитивную аппроксимацию рамного профиля, что демонстрирует оригинальность нового подхода.

Ключевые слова: вентиляционная выработка, горное давление, крепь, деформации, компьютерное моделирование

\section{ARTICLE INFO}

Received: 27 November 2015

Accepted: 13 January 2016

Available online: 30 March 2016

\section{ABOUT AUTHORS}

Victor Nazymko, Doctor of Sciences (Engineering), Senior researcher, Institute for Physics of Mining Processes the National Academy of Sciences of Ukraine (IFGP NAS of Ukraine), 2a Simferopolska St, 49005, Dnipropetrovsk, Ukraine. E-mail: victor.nazimiko@yahoo.com

Volodymyr Griniov, Doctor of Sciences (Engineering), Director, Institute for Physics of Mining Processes the National Academy of Sciences of Ukraine (IFGP NAS of Ukraine), 2a Simferopolska St, 49005, Dnipropetrovsk, Ukraine. E-mail: grinevv@ukr.net 